\title{
Feeding habitat of the understory arboreal snail Tikoconus costarricanus (Stylommatophora: Euconulidae) in a tropical montane wet forest, Costa Rica
}

\author{
Zaidett Barrientos ${ }^{1}$ iD \\ Received 24-IX-2020 • Corrected 11-XII-2020 • Accepted 13-XII-2020 \\ DOI: https://doi.org/10.22458/urj.v13i1.3311
}

1. Laboratorio de Ecología Urbana, Universidad Estatal a Distancia, 2050 San Jose, Costa Rica; zbarrientos@uned.ac.cr

\begin{abstract}
Introduction: The feeding habitats of land snails are essential for their survival. Some are little known, for example the upper surface of leaves, habitat of tropical arboreal and shrub snails. Objective: To analyze the feeding behavior and preferences in the feeding habitat of the tropical snail Tikoconus costarricanus. Methods: In a humid montane tropical forest in Cartago, Costa Rica, I recorded every 3 to 4 hours the feeding activity and general behavior of individually marked snails on a $2 \mathrm{~km}$ trail (seven 24 -hour visits in May 2010-March 2011). Results: I observed a total of 167 individual specimens and made 781 observations about their behavior and the leaves on which they were found. These snails preferred monocotyledonous leaves with many epiphylls, despite the fact that those leaves were not common in this forest. They avoided ferns, and during the less rainy season, they preferred leaves with many trichomes, although there were few such leaves. On average, they spent 11 hours on each individual leaf and visited two leaves per day. The few snails seen on stems were almost always moving, as opposed to those on the leaf underside. On average they moved a net $65 \mathrm{~cm}$ each day. Feeding concentrated around 9:00 am and defecation around 4:20 am. Conclusions: These snails prefer leaves with many epiphylls, where they find good camouflage, moisture and food. The preference for trichomes could be due to mechanical reasons. The lack of seasonality in their behavior may reflect their stable food source in a forest that remains humid year round.
\end{abstract}

Keywords: Epiphylls, feeding, land snails, microhabitat, seasonality.
RESUMEN. "Hábitat de alimentación del caracol arborícola de sotobosque Tikoconus costarricanus (Stylommatophora: Euconulidae) en un bosque tropical húmedo montano, Costa Rica". Introducción: Los hábitats de alimentación de los caracoles terrestres son esenciales para su supervivencia. Algunos son poco conocidos, como el haz de las hojas, hábitat de caracoles tropicales arborícolas y arbustícolas. Objetivo: Analizar comportamientos y preferencias de hábitat en Tikoconus costarricanus. Métodos: En un bosque tropical húmedo montano de Cartago, Costa Rica, registré cada 3 a 4 horas la actividad de caracoles individualmente marcados en un sendero de $2 \mathrm{~km}$ (siete visitas de un día entre mayo 2010 y marzo 2011). Resultados: Observé 167 especímenes e hice 781 observaciones. Estos caracoles prefirieron las escasas hojas monocotiledóneas y con muchos epífilos. Evitaron los helechos y durante la época con menos lluvia prefirieron hojas con muchos tricomas, a pesar de que había pocas. En promedio pasaron 11 horas en cada hoja y visitaron dos hojas por día. Los pocos caracoles vistos en tallos casi siempre se estaban desplazando, al contrario de los que estaban en el envés. En promedio se desplazaron $65 \mathrm{~cm}$ netos cada día. La alimentación se concentró alrededor de las 9:00am y la defecación alrededor de las 4:20 am. Conclusiones: Esta especie prefiere hojas con muchos epífilos donde encuentran mejor camuflaje, humedad y alimento. La preferencia por los tricomas podría deberse a razones mecánicas. Su falta de estacionalidad puede deberse que a su fuente de alimento es estable en un bosque que permanece húmedo todo el año.

Palabras clave: Epífilos, alimentación, caracoles terrestres, microhábitat, estacionalidad. 
Food presence is one of the main factors that determine land snail distribution (Puslednik, 2002); however, despite their importance for conservation management, very little is known about the feeding preferences, biology, and habitat of Neotropical land mollusks.

Many researchers have reported apparent snail preferences for specific plants as food or as substrate (Mason, 1970; Fernández, Peña, Reyes, \& Monteagudo, 2001; Reyes-Tur \& GonzálezRodríguez, 2003; Carbonell-Lebren, Reyes, Fernández-Abreu, Velázquez, \& Iglesias-Matos, 2012; Meyer et al., 2014). Some arboreal species like Coryda Alauda strobilus and Polymita muscarum prefer to be on branches. Others, like Caracolus sagemon rostrate and Liguus fasciatus achatinus prefer trunks, while others, like the Cuban Jeanneretia bicinta, Polymita picta and Hemitrochus lucipeta. Finally, the Costa Rican T. costarricanus prefer leaves (Bidart \& Espinosa, 1989; Bidart, Osorio, Reynaldo, Fernández \& Iglesias, 1992; Suárez \& Fernández, 2012; Hernández, 2013; Barrientos, 2020a).

Most papers dealing with snail food preferences refer to plant palatability and feeding preferences, especially if they are pests (Andrews, Valverde, \& Ramírez, 1985; Thakur, 1998; Peters, Baur, Bazzaz, \& Körner, 2000; Speiser, 2001; Puslednik, 2002; Dourson, 2008; Meyer et al., 2014). However, many species do not eat plants. Many tropical native tree snails feed on corticolous lichens (Reyes-Tur, González-Guillén, Rosabal, \& Capote-Danet, 2020) or on epiphytic flora, including epiphylls. Species of genus Orthalicus feed on epiphytic algae growing on trunks and leaves (Craig, 1972). In Hawaii, arboreal snails are believed to graze on epiphytic fungi growing on the underside of leaves (Meyer et al., 2014). In Costa Rica, T. costarricanus has been reported grazing on epiphylls (Barrientos, 2020a). Even the Japanese arboreal snail Euhadra brandtii sapporo grazes on epiphytic lichens and mosses (Saeki et al., 2017). Epiphylls are common in tropical forests, however, little is known about general characteristics like epiphyll and trichome cover, leaf density, size, shape among other anatomical and chemical characteristics, and about interactions between epiphylls, leaves and other species that share this microhabitat, including snails (Wäreborn, 1970; Coley, Kursar, \& Machado, 1993; Coley \& Kursar, 1996; Lücking \& Bernecker-Lücking, 2000; Meyer et al., 2014).

Leaf trichomes occur in many forms and affect leaf temperature, water loss, light reflectance, and water economy (Wagner, 1991; Gonzáles, Negritto, Suarez, \& Gianoli, 2008). Trichomes can also store secondary metabolites that avoid herbivory, and their exudates can be antifungal, antibiotic and antimicrobial (Levin, 1973; Wagner, 1991; Nonomura et al., 2009). Non-glandular trichomes are also considered physical barriers that deter herbivores (Kariyat, Smith, Stephenson, De Moraes, \& Mescher, 2017). Nevertheless, few papers have analyzed leaf palatability according to pubescence. No clear preference has been found, some species like Succinea putris and Urticicola umbrosus prefer to eat plants with dense pubescence, while others, like Arion spp. prefer glabrous leaves (Westerbergh \& Nyberg, 1995; Podroužková, Janovský, Horáčková, \& Juřičková, 2015). Beside this, I did not find information about snail trichome preference when leaves are used as substrate.

The semislug Tikoconus costarricanus inhabits understory shrubs in Costa Rican humid and well-preserved understories (Barrientos, 2019). Relative humidity, temperature, rain, canopy drip from fog, dew and rain are determinant factors in activity peaks, leaf side selection according to daytime, and vertical distribution (Barrientos, 2020a, 2020b). However, substrate preferences, feeding time and daily displacement are unknown. In this paper I analyzed $T$. costarricanus' feeding habitat and behavior. 


\section{MATERIALS AND METHODS}

I conducted this study in the Reserva Forestal Río Macho in a tropical montane wet forest (Costa Rica) $\left(9^{\circ} 45^{\prime} 56.07^{\prime \prime} \mathrm{N}, 83^{\circ} 51^{\prime} 47.11^{\prime \prime} \mathrm{W}, 1640\right.$ masl). I searched for specimens of $T$. costarricanus on a $2 \mathrm{~km}$ long, fixed trail, during seven 24-hour periods in May 2010 - March 2011. I sampled every 34 hours; each sampling took one to two hours. During the first sampling of each day, I searched for snails on shrubs at both sides of the trail. When I found a snail, I made sure that no more snails were on that particular plant. I placed a conspicuous mark on the trail: this allowed me to find the place during night surveys. I also marked the shrub with red flagging and an individual number. I attached a small red ribbon to the stem with the snail and drew a small dot with white indelible ink besides the snail; after the first survey, I erased the previous dot.

On each occasion I observed the snails for less than 15 seconds and I took note of the snail's location in the forest and in the part of the plant in which they were located (underside or upper side of leaves or twigs). I also took note of leaf type (monocotyledon, dicotyledon or fern); daytime and season; if they were feeding or not and number of droppings; visible epiphyll cover of the leaf with the snail (my personal visual estimate in four categories: very low, 0-25\%; low, 26-50\%; medium, 51\%-75\%; and high, 76-100\%), to determine percentages I divided each leaf in four quadrants, $25 \%$ each; trichome cover: none for glabrous leaves, low when trichome density was 5 or less trichomes per $\mathrm{cm}^{2}$ or high if there were more than 5 trichomes per $\mathrm{cm}^{2}$; I also noted if the snail was moving or not; any snail displacement, and if they snail had moved to a different leaf. When possible, I followed the snail mucous trail and measured displacement considering the white dot that I had drawn in the previous survey, otherwise, and based on my personal experience from watching dozens of these snails moving on leaves, I recorded the simplest and shortest trail that the snail could have followed.

I excluded specimens on twigs from epiphyll, leaf type and trichome preferences and from feeding and defecation time analyses. I calculated total displacement in 24 -hour periods by adding all the displacements recorded for each specimen within the period. I calculated time spent on each leaf by adding the time between each sampling whenever I found the snail in the same leaf. As several hours passed between samplings, time spent on each leaf and displacement results represent the minimum quantity. For a detailed methodology see Barrientos (2020b).

To prevent the bias that could result from only measuring characteristics in leaves occupied by snails, I also sampled epiphyll cover, leaf trichome cover and leaf type occurrence in the understory in general. I used this information as a base line or reference to compare with the leaves that did have snails. For this reference, I used a random generator to select 20 numbers between 0 and 60 . These numbers corresponded to the minutes in one hour walk (about $3 \mathrm{~km} / \mathrm{hour}$ ) when I stopped to take photos and leaf samples. The side of the trail (left or right) in which I worked was also randomly selected in advance. I photographed each collecting place with a Sony camera (DSLR-A350; 14,2 megapixels) with an $18-70 \mathrm{~mm}$ macro lens located $160 \mathrm{~cm}$ above the ground. Afterwards, two assistants collected leaves between 0 and $200 \mathrm{~cm}$ above ground for 30 seconds, for epiphyll and trichome cover analysis. I analysed these variables only once in the study period, since wet tropical montane plants remain alive and with the same foliage throughout the year, so no significant seasonal change was expected.

In the laboratory, I used a standardized grid with 345 evenly distributed dots digitally overlaid on each photograph to establish the reference percentage of monocotyledon, dicotyledon and fern leaves in the wild. For this purpose, I counted the number of dots falling over monocotyledon, dicotyledon and fern leaves in the sampling site photographs. I did not count dots above trunks, soil, dead leaves, sky, unidentifiable leaves, or twigs. I also classified each collected leaf in the corresponding epiphyll and trichome cover category. 
Voucher specimens: I deposited voucher specimens in the Zoology Museum of the University of Costa Rica. Catalogue number MZUCR- 242-01 (9 specimens). Costa Rica, Cartago, Orosi, Reserva Forestal Río Macho, at "El llano" water dam. 1640 masl. 945'56.07"N, 8351'47.11"W. collected on 5 March 2012 by Zaidett Barrientos, Maribel Zúñiga \& Andrea Induni. (T.: ZB-251).

\section{RESULTS}

I observed 167 specimens of $T$. costarricanus. I made 781 observations in total; 769 observations with specimens that were on, or under leaves, and only 12 observations with specimens on twigs. For leaf type percentage in the understory, I made 1503 observations. For leaf epiphyll and trichome cover in the understory I made 485 observations.

Epiphyll cover preference: In the reference -epiphyll cover percentage in the understory- I found that $75 \%$ of the leaves had very low epiphyll cover, $15 \%$ had low cover, $7 \%$ had medium cover and $3 \%$ had high epiphyll cover (sample size= 485) (Fig.1).

I found no difference between seasons on the snail's epiphyll cover preference (Chi square: $\chi^{2}=6,91 ; D f=3 ; p=0,0748 ; n=769$ ). I found more snails on leaves with very low epiphyll cover (Fig. 1). However, when I compared snail's epiphyll cover preference with the reference (epiphyll cover in the understory), I found that this species tended to be on leaves with more epiphylls visible to the naked eye, although those leaves were scarce $\left(x^{2}=50,59 ; \mathrm{Df}=3 ; p<0,0001 ; n=1254\right)$ (Fig. 1). For example, although only $3 \%$ of the leaves in the understory had high epiphyll cover, $11 \%$ of the leaves in which I found $T$. costarricanus were almost completely covered by epiphylls.

Leaf type preference: In the reference -leaf type percentage in the understory- I found: $76 \%$ dicotyledonous, $16 \%$ ferns and $8 \%$ monocotyledonous (sample size= 1 503) (Fig. 2). But, when I analyzed the type of leaves where the snails were, I found that they preferred being on dicotyledon leaves, followed by monocotyledon leaves and ferns, although monocotyledon leaves were the less common in the understory $\left(x^{2}=110,93 ; D f=4 ; p<0,0001 ; n=2272\right)$ (Fig. 2). Snail's leaf type selection was affected by season and neither fit the reference (Dry season: $\chi^{2}=66,74 ; D f=2 ; p<0,0001 ; n=2006$; Rainy season: $\chi^{2}=64,89 ; D f=2 ; p<0,0001, n=1769$ ) (Fig. 2). Fern avoidance was clearer during the rainy season.

Trichome cover preference: In the reference understory, most leaves were glabrous (83\%), followed by leaves with low trichome cover (14\%). The less common leaves were those with high trichome cover (3\%) (Fig. 3).

Snail trichome cover preference varied with seasons $\left(\chi^{2}=18,73 ; \mathrm{Df}=2 ; p<0,0001 ; n=769\right)$ (Fig. $3)$. During the rainy season, snail trichome preference fits leaf trichome cover distribution on the understory $\left(x^{2}=5,09 ; D f=2 ; p=0,0785 ; n=751\right)$ (Fig. 3). However, during the dry season snails preferred being on leaves with high trichome cover $(8 \%)$ despite their scarcity in the understory $\left(\chi^{2}=12,55 ; \mathrm{Df}=2\right.$; $p=0,0019 ; n=988$ ) (Fig. 3). 


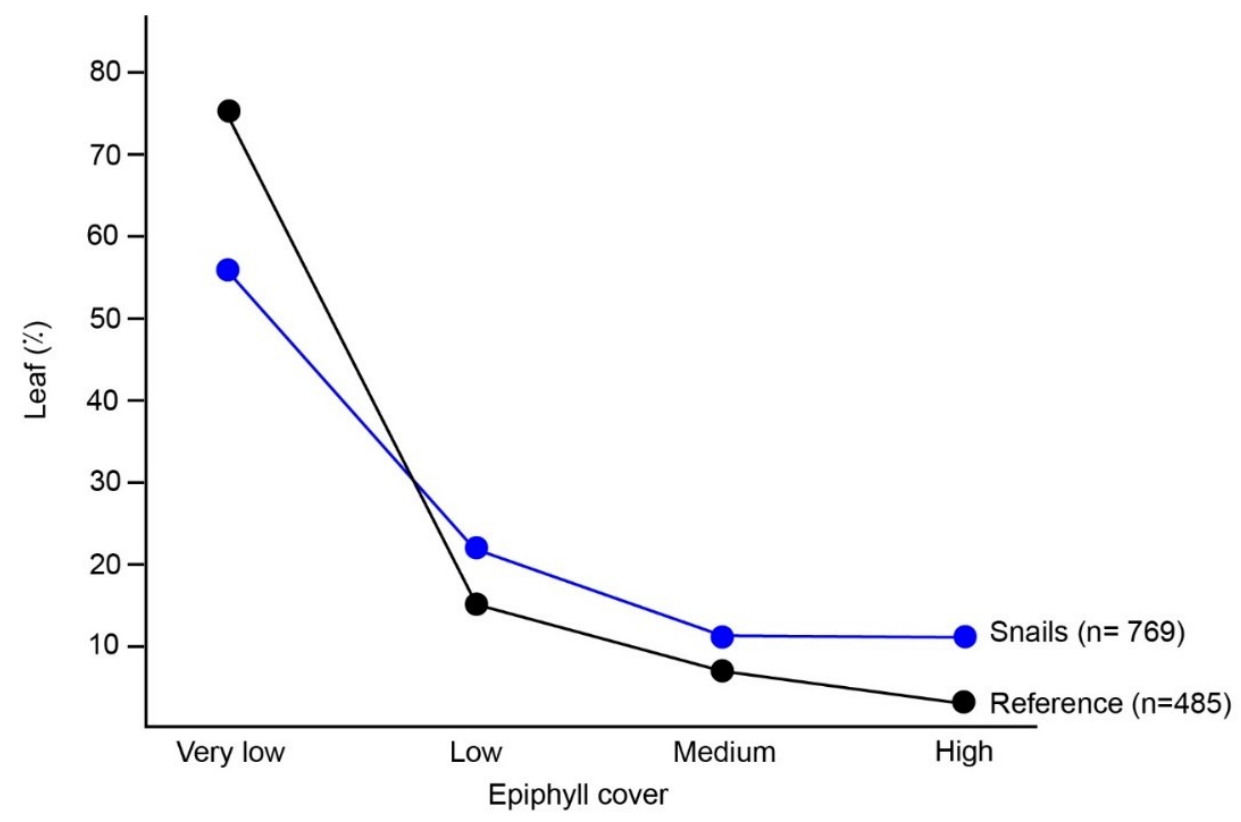

Fig. 1. Leaf epiphyll cover on leaves with $T$. costarricanus (snails) compared to leaf epiphyll cover in the understory used as reference.

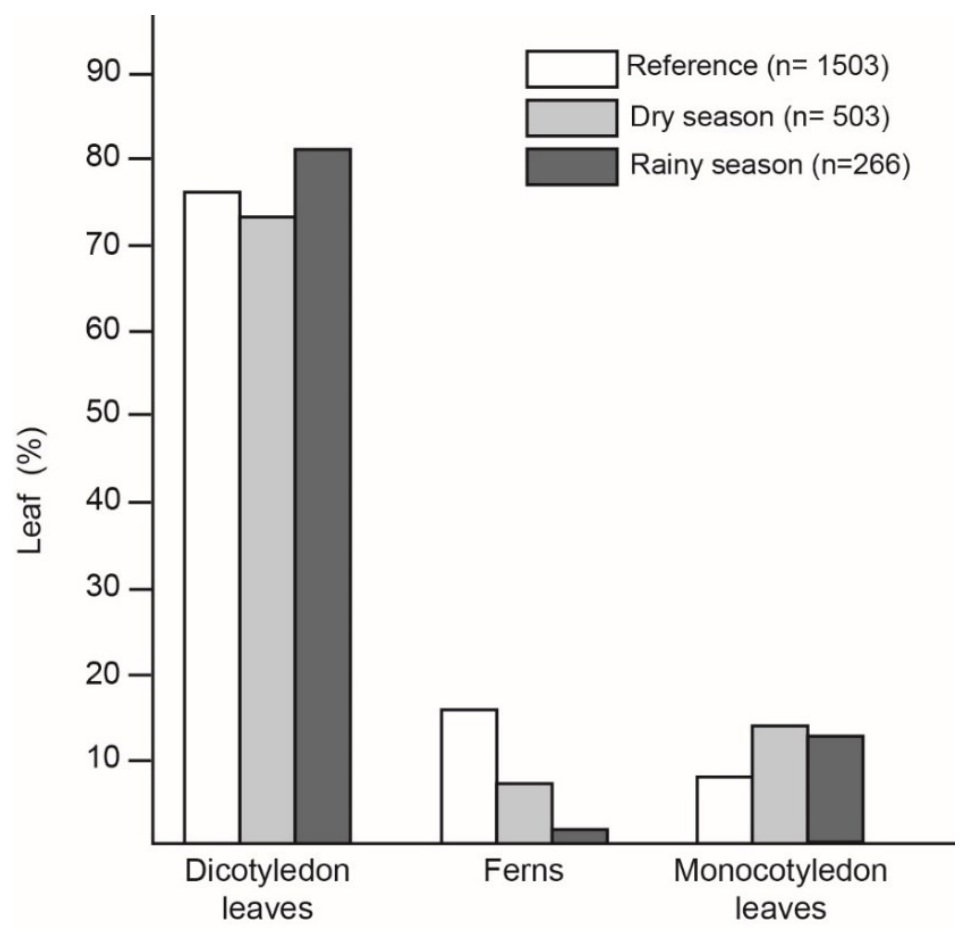

Fig. 2. Leaf type percentage with $T$. costarricanus according to season compared to leaf type percentage in the understory used as reference. 


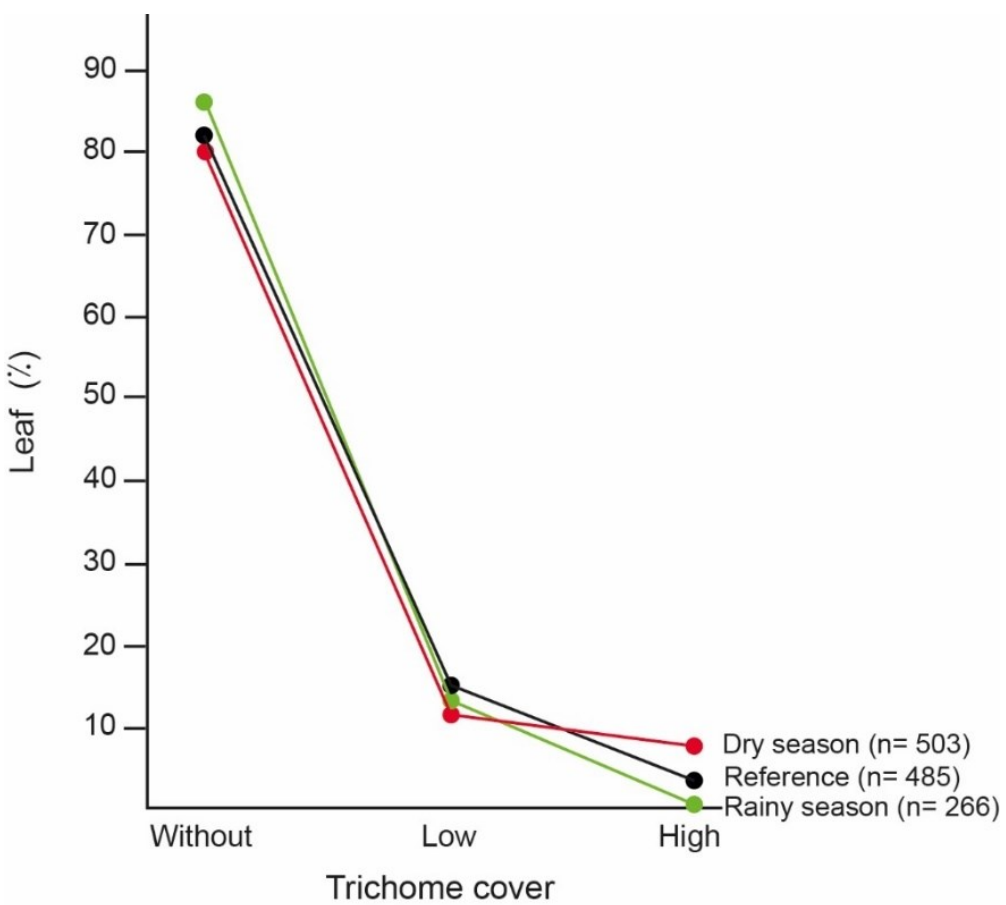

Fig. 3. Trichome cover on leaves with $T$. costarricanus according to season, compared to trichome cover on leaves in the understory used as reference.

Time spent on each leaf and leaf number visited in $\mathbf{2 4}$ hours: I found no difference between seasons in the time snails spent in a particular leaf (Mann-Whitney; $W=2564 ; p=0,131583$; $\mathrm{n}=163$ ). In average they spent at least 10,91 hours on each leaf ( $\min .=0,88 ; \max .=24,5 ; S D=6,42 ; n=$ 163). I also did not find differences between seasons in the number of leaves visited in a 24-hour period (Mann-Whitney; $W=2$ 152; $p=0,112408 ; n=147$ ). In average they visited 2,13 leaves in a 24hour period $(\min .=1 ; \max .=5 ; S D=1,15 ; n=147)$.

Displacement: I found more snails moving when they were on twigs ( $92 \%$, sample size $=12$ ), followed by those that were on the upper side of leaves $(33 \%$, sample size=186). Snails on the underside of leaves were seldom moving $(6 \%$, sample size $=583)$. Their daily displacement did not change between seasons with 0,01 confidence (Mann-Whitney; $W=3$ 048; $p=0,0382817 ; n=147$ ). In a 24-hour period, snails had an average displacement of $65 \mathrm{~cm}(\min =0 \mathrm{~cm} ; \max =257 \mathrm{~cm} ; \mathrm{SD}=51,82$; sample size=147).

Feeding time: Only $1,6 \%$ of the observations (sample size $=769$ ) include a snail that was feeding. All were on the upper side of leaves. I found this species feeding at 8:57 a. $\mathrm{m}$. in average (min= 5:27 a. $m$.; $\max =12: 35$ p. $m . ; S D=1,95$; sample size=11). I found only one specimen feeding at 21:04 pm during the dry season, I did not include this record in the statistical analysis.

Defecation time: I found fresh droppings only in $2 \%$ of the observations (sample size= 769 ). All were on the underside of leaves; on average they defecated at 4:22 a. m. (min= 1:40 a. m.; max= $5: 23$ a. m.; $S D=1,07$; sample size=16). I found that $90 \%$ of the specimens with fresh droppings had one fresh dropping, the rest had two fresh droppings (only one specimen had four fresh droppings). Beside these records, I observed other 132 fresh droppings while working in the field; all were on the underside of leaves. 


\section{DISCUSSION}

Epiphylls are the main food of $T$. costarricanus - and probably of other shrub euconulidsexplaining why they prefer leaves with more epiphylls despite their scarcity in the forest (MongeNájera, 1989; Coley et al., 1993; Monge-Nájera \& Blanco, 1995; Lücking \& Bernecker-Lücking, 2000). Epiphylls also provide camouflage (Barrientos, 2019) and probably moisture (Wiesenborn, 2003; Barrientos, 2019). Lücking \& Bernecker-Lücking (2000) found that land mollusks (an euconulid as I can identify from the figure) feed more often on lichens with high content of calcium oxalate crystals. Terrestrial gastropods can also be very specific in the kind of lichen they eat: if they have the opportunity, they prefer lichens that allow juveniles to gain more weight (Baur, Baur, \& Fröberg, 1994).

Many season-independent activities are determined by environmental conditions that are stable along the year. In the studied forest, leaf litter humidity is high and stable all year around, creating a very humid and stable understory environment (Barrientos, 2012; Aparecido et al., 2018). Under these circumstances, leaves seldom fall and epiphylls grow constantly, therefore it is not a surprise that T. costarricanus' epiphyll cover selection, time spent on each leaf, and leaves visited, have no seasonal differences. Displacement is also similar in both seasons, maybe because food search is the main reason for land mollusk displacement (Cook, 2001; Speiser, 2001); in other words, if food is constant regardless of the season, no extra displacement is needed. Time spent on each leaf, and number of leaves visited, need more research, I presume that they are related with epiphyll cover and leaf size and shape.

On the contrary, it is quite unexpected that the preferred leaf type changes with seasons. Many researchers found that land snails tend to be on the most abundant plants (Chatfield, 1976; Williamson \& Cameron, 1976; Szlávecz, 1986; Speiser \& Rowell-Rahier, 1991; Hatziioannou, Eleutheriadis, \& Lazaridou-Dimitriadou, 1994; Iglesias \& Castillejo, 1999). In the case of $T$. costarricanus, most snails were on dicotiledonean leaves, which were the more abundant leaf type in the understory. However, there was a tendency to avoid ferns and to select monocotiledonean leaves, especially during the rainy season. Possible explanations can be divided into chemical and morphological causes. Future work should test if fern, or monocotiledonean secondary metabolites or stemflow, affect epiphyll growth the snail's main food source- or calcium availability (Wink, 1988; Vetter, 2018; Ohta \& Saeki, 2020). Among the morphological reasons, fern pinnae and pinnule epidermis and shape may encumber snail displacement (Gorb, 2008) or they may favor canopy drip, exposing snails to be washed away from leaves (Dean \& Smith, 1978; Monge-Nájera \& Blanco, 1995; Gorb, 2008; Meyer et al., 2014; Barrientos 2020b). On the contrary, monocotyledonous leaves may offer more protection against environmental factors.

Snails were more often found on leaves without trichomes, not only because such leaves are the most common, but probably also because trichomes may have phytotoxin oils or secondary metabolites that suppress epiphyll establishment or react to their slime and crawling (Wagner, 1991; Nonomura et al., 2009). However, seasonal differences on leaves with high trichome cover suggest structural interactions. During the dry season leaves with many trichomes better reflect visible light and infrared radiation, and this may help snails regulate their temperature during the day (Bickford, 2016). At the same time, trichomes may prevent heat loss by creating an air layer during the dry season nights (Westerbergh \& Nyberg, 1995).

The mean daily distance that land snail travel depends on food availability but also on snail size (Baur \& Baur, 1988; Cook, 2001). Snails of the genus Xeropicta are similar in size to T. costarricanus but live in a subtropical region. The maximum distance Xeropicta travel in a day is similar to what $T$. costarricanus travels, but on average, each day, Xeropicta travels twice the distance (Popov \& Kramarenko, 2004). Food abundance in tropical montane regions explains why $T$. costarricanus needs 
to travel less, but physiological limitations explain why similar-sized species share the same maximum distance traveled in a day.

Twigs are not the preferred substrate of $T$. costarricanus (Barrientos, 2020b). Most snails on twigs were moving probably because they slide on them only while changing from one leaf to another. As shown by Barrientos (2020b), T. costarricanus avoids being on the upper side of leaves -although they feed there- because rain and canopy drip are dangerous for them. In contrast, the underside of leaves offers protection, therefore, more resting snails can be found in this part of the leaves (Barrientos, 2020b). Feeding time is explained by daily rain pattern and canopy drip from rain and dew during the rainy season fog (Barrientos, 2020b). During the dry season feeding time is explained by daily temperature and relative humidity patterns and by canopy drip from dew and fog (Barrientos, 2020b).

It is not known if land snails produce feces continuously, accumulate and release them periodically or if they are produced and released immediately (Dimitriadis, 2001). It is also not known if defecating is a risky activity, for example preventing them from defensive shell rotation or foot twisting (Barrientos, 2020a). Therefore, it is better to do it under the protection of the leaf. Daily endogenous cycles have been described for Deroceras panormitanum (Dimitriadis, 2001); it is possible that also T. costarricanus and Polymita muscarum have endogenous cycles that explain why they defecate around 4:00am, regardless of the season (Reyes-Tur, Flores-Ricardo \& Fernández-Velázquez, 2018).

Neotropical arboreal and shrub snail behavior and ecological requirements are still poorly understood. Understory composition and structure are relevant in the conservation of the feeding habitat of $T$. costarricanus.

\section{ACKNOWLEDGEMENTS}

Maribel Zúñiga Solís, Gabriela Pérez Gómez and Andrea Induni Vizcaino gave field and technical assistance. Julián Monge-Nájera, Edna Naranjo, Edmund Gittenberger and Fred Thompson helped improved this paper. Ligia Bermudez and Greibin Villegas provided statistical advice.

This paper was partially financed by the project "FEES-CONARE Análisis ecosistémico para la evaluación de la restauración forestal y sus implicaciones en el secuestro de carbono en un bosque nublado" and by the UNED's Research Vice-presidency.

\section{ETHICAL, CONFLICT OF INTEREST AND FINANCIAL STATEMENTS}

The author declares that she has fully complied with all pertinent ethical and legal requirements, both during the study and in the production of the manuscript; that there are no conflicts of interest of any kind; that all financial sources are fully and clearly stated in the acknowledgements section; and that she fully agrees with the final edited version of the article. A signed document has been filed in the journal archives.

The statement of each author's contribution to the manuscript is as follows: Z.B.: is the sole author. 


\section{REFERENCES}

Andrews, K., Valverde, V.H., \& Ramírez, O. (1985). Preferencia alimenticia de la babosa, Sarasinula plebeia (Fisher). Ceiba, 26(1), 59-65.

Aparecido, L. M. T., Teodoro, G. S., Mosquera, G., Brum, M., Barros, F. D. V., Pompeu, P. V., ... \& Asbjornsen, H. (2018). Ecohydrological drivers of Neotropical vegetation in montane ecosystems. Ecohydrology, 11(3), 1-17. DOI: 10.1002/eco.1932

Barrientos, Z. (2012). Dynamics of leaf litter humidity, depth and quantity: two restoration strategies failed to mimic ground microhabitat conditions of a low montane and premontane forest in Costa Rica. Revista de Biología Tropical, 60(3), 1041-1053.

Barrientos, Z. (2019). Demography of the land snail Tikoconus (Tikoconus) costaricanus (Stylommatophora: Euconulidae) in tropical low montane and premontane forests, Costa Rica. Revista Biología Tropical, 67(6), 1449-1460. DOI: 10.15517/RBT.V6716.36201

Barrientos, Z. (2020a). A new aestivation strategy for land molluscs: hanging upside down like bats. UNED Research Journal, 12(1), e2802. DOI: 10.22458/urj.v12i1.2802

Barrientos, Z. (2020b). Microhabitat selection, and season and daily activity of the land snail Tikoconus costarricanus (Stylommatophora, Euconulidae) in tropical montane wet forest understory. Revista Biología Tropical, 68(4), 11311142.

Baur A., \& Baur, B. (1988). Individual movement patterns of the minute land snail Punctum pygmaeum (Draparnaud) (Pulmonata: Endodontidae). Veliger, 30(4), 372-376. Retrieved from https://www.biodiversitylibrary.org/page/42468278\#page/393/mode/1up

Baur, A., Baur, B., \& Fröberg, L. (1994). Herbivory on calcicolous lichens: different food preferences and growth rates in two co-existing land snails. Oecologia, 98(3-4), 313-319.

Bickford, C. P. (2016). Ecophysiology of leaf trichomes. Functional Plant Biology, 43(9), 807-814. DOI: 10.1071/FP16095

Bidart, L., \& Espinosa, J. (1989). Aspectos del nicho ecológico de Polymita picta nigrolimbata, Caracolus sagemon rostrata y Coryda alauda strobilus. Ciencias biológicas, (21-22), 130-135.

Bidart, L., Osorio, M., Reynaldo, E., Fernández, J., \& Iglesias, C. (1992). Nicho ecológico de Polymita muscarum, Liguus fasciatus achatinus y Hemitrochus lucipeta. Ciencias Biológicas, 25, 9-19.

Carbonell-Lebren, Y., Reyes, B., Fernández-Abreu, I., Velázquez, Y., \& Iglesias-Matos, L. (2012). Plantas usadas como sustrato por Polymita picta, Caracolus sagemon y Coryda alauda en el bosque secundarios y matorral xeromorfo costero del elemento natural destacado Yara-Majayara, Baracoa, Guantánamo, Cuba. Hombre, Ciencia y Tecnología, 16(3), 6575. Retrieved from http://www.ciencia.gtmo.inf.cu/index.php/http/article/view/327

Chatfield, J.E. (1976). Studies on food and feeding in some European land molluscs. Journal of Conchology, 29: 5-20.

Coley, P. D., \& Kursar, T. A. (1996). Causes and consequences of epiphyll colonization. In: S.S. Mulkey, R.L. Chazdon, A.P. Smith (eds). Tropical Forest Plant Ecophysiology. (pp. 337-362) Boston, MA, USA: Springer. DOI: 10.1007/978-1-4613-11638_12

Coley, P.D., Kursar, T.A., \& Machado. J.L. (1993). Colonization of tropical rain forest leaves by epiphylls: effects of site and host plant leaf time. Ecology, 74(2), 619-623. Retrieved from http://www.swarthmore.edu/NatSci/jmachad1/publications/Coley_et_al_94.pdf, DOI: 10.2307/1939322

Cook, A. (2001). Behavioural Ecology: On Doing the Right Thing, in the Right Place at the Right Time. In: Barker, G.M. (ed). The biology of terrestrial mollusks (pp. 447-488.). New York, USA: CABI publishing. 
Craig, A. K. (1972). Observations on the arboreal snail Orthalicus floridensis. Quarterly Journal of the Florida Academy of Sciences, 35(1), 15-20.

Dean, J. M., \& Smith, A. P. (1978). Behavioral and morphological adaptations of a tropical plant to high rainfall. Biotropica, 10(2), 152-154. DOI: $10.2307 / 2388018$

Dimitriadis, V. K. (2001). Structure and Function of the Digestive System in Stylommatophora. In: G.M. Barker (ed). The biology of terrestrial mollusks (pp. 237-257). New York, USA: CABI publishing.

Dourson, D. C. (2008). The feeding behavior and diet of an endemic West Virginia land snail, Triodopsis platysayoides. American Malacological Bulletin, 26(1/2), 153-159. DOI: 10.4003/006.026.0215

Fernández, A., Peña, C., Reyes, E., \& Monteagudo, S. (2001). Relación planta-molusco y estado de conservación de colonias de Polymita muscarum Lea 1834, en zona costera de Holguín, Cuba. Revista Ciencias Holguín, 7(2), 1-11. Retrieved from http://www.ciencias.holguin.cu/index.php/cienciasholguin/article/view/157

Gonzáles, W. L., Negritto, M. A., Suarez, L. H., \& Gianoli, E. (2008). Induction of glandular and non-glandular trichomes by damage in leaves of Madia sativa under contrasting water regimes. Acta oecologica, 33(1), 128-132

Gorb, S. N. (2008). Biological attachment devices: exploring nature's diversity for biomimetics. Philosophical Transactions of the Royal Society of London A: Mathematical, Physical and Engineering Sciences, 366(1870), 1557-1574.

Hatziioannou, M., Eleutheriadis, N., \& Lazaridou-Dimitriadou, M. (1994). Food preferences and dietary overlap by terrestrial snails in Logos area (Edessa, Macedonia, Northern Greece). Journal of Molluscan Studies, 60(3), 331-341. DOI: $10.1093 /$ mollus/60.3.331

Hernández, M. (2013). Occupancy of strata of plant height and plant substrate by land snail (Gastropoda) assemblages at Escaleras de Jaruco, Mayabeque, Cuba. The Nautilus, 127(1), 29-35.

Iglesias, J., \& Castillejo, J. (1999). Field observations on feeding of the land snail Helix aspersa Muller. Journal of Molluscan Studies, 65(4), 411-423.

Kariyat, R. R., Smith, J. D., Stephenson, A. G., De Moraes, C. M., \& Mescher, M. C. (2017). Non-glandular trichomes of Solanum carolinense deter feeding by Manduca sexta caterpillars and cause damage to the gut peritrophic matrix. Proceedings of the Royal Society B: Biological Sciences, 284(1849), 20162323. DOI: 10.1098/rspb.2016.2323

Levin, D. A. (1973). The role of trichomes in plant defense. The quarterly review of biology, 48(1, Part 1), 3-15.

Lücking, R., \& Bernecker-Lücking, A. (2000). Lichen feeders and lichenicolous fungi: do they affect dispersal and diversity in tropical foliicolous lichen communities. Ecotropica, 6(1), 23-41.

Mason, C. F. (1970). Food, feeding rates and assimilation in woodland snails. Oecologia, 4(4), 358-373.

Meyer, W. M., Gary, D. T., Yeung, N. W., Dirks, C., Leung, K., Léon, J. A., ... \& Hayes, K. A. (2014). Native arboreal land snails in the Mt Kaala Natural Area Reserve, Oahu, Hawaii, have similar plant preferences: implications for conservation. Journal of Molluscan Studies, 80(4), 469-472. DOI: 10.1093/mollus/eyu065

Monge-Nájera, J. (1989). The relationship of epiphyllous liverworts with leaf characteristics and light in Monte Verde, Costa Rica. Cryptogamie, Bryologie, 10(4), 345-352

Monge-Nájera, J., \& Blanco, M. A. (1995). The influence of leaf characteristics on epiphyllic cover: a test of hypotheses with artificial leaves. Tropical Bryology, 11, 5-9. DOI: 10.11646/bde.11.1.3

Nonomura, T., Xu, L., Wada, M., Kawamura, S., Miyajima, T., Nishitomi, A., ... \& Toyoda, H. (2009). Trichome exudates of pennellii form a chemical barrier to suppress leaf-surface germination of Oidium neolycopersici conidia. Plant Science, 176(1), 31-37. DOI: 10.1016/j.plantsci.2008.09.002 
Ohta, T., \& Saeki, I. (2020). Comparisons of calcium sources between arboreal and ground-dwelling land snails: implication from strontium isotope analyses. Journal of Zoology, 311(2), 137-144. DOI: 10.1111/jzo.12767

Peters, H. A., Baur, B., Bazzaz, F., \& Körner, C. (2000). Consumption rates and food preferences of slugs in a calcareous grassland under current and future $\mathrm{CO}_{2}$ conditions. Oecologia, 125(1), 72-81. DOI: 10.1007/PL00008893

Podroužková, Š., Janovský, Z., Horáčková, J., \& Juřičková, L. (2015). Do snails eat exotic plant species invading river floodplains? Journal of Molluscan Studies, 81(1), 139-146. DOI: 10.1093/mollus/eyu073

Popov, V. N., \& Kramarenko, S. S. (2004). Dispersal of land snails of the genus Xeropicta Monterosato, 1892 (Gastropoda; Pulmonata; Hygromiidae). Russian Journal of Ecology, 35(4), 263-266. DOI: 10.1023/B:RUSE.0000033797.51636.83

Puslednik, L. (2002). Dietary preferences of two species of Meridolum (Camaenidae: Eupulmonata: Mollusca) in southeastern Australia. Molluscan Research, 22(1), 17-22.

Reyes-Tur, B., Flores-Ricardo, L. A., \& Fernández-Velázquez, A. (2018). Actividad diaria de Polymita muscarum (Gastropoda: Cepolidae) en un agroecosistema: relación con factores climáticos y duración del apareamiento/Daily activity of Polymita muscarum (Gastropoda: Cepolidae) in an agroecosystem: relationship with climatic factors and mating duration. Revista Cubana de Ciencias Biológicas, 6(1), 9.

Reyes-Tur, B., \& González-Rodríguez, A. (2003). Relación planta-animal del molusco terrestre Cubano Polymita venusta (Gmelin, 1792), (Stylommatophora: Helminthoglyptidae) en sardinero, Santiago de Cuba, Cuba. Biología, 17(2), 134 142.

Reyes-Tur, B., González-Guillén, A., Rosabal, D., \& Capote-Danet, A. (2020): Associations between tree snails and corticolous lichens in a secondary forest in eastern Cuba. Poeyana, 510, 18-26.

Saeki, I., Niwa, S., Osada, N., Hyodo, F., Ohta, T., Oishi, Y., \& Hiura, T. (2017). Adaptive significance of arboreality: field evidence from a tree-climbing land snail. Animal Behaviour, 127, 53-66. DOI: 10.1016/j.anbehav.2017.02.022

Speiser, B. (2001). Food and feeding behaviour. In: G. M. Barker (ed). The biology of terrestrial mollusks. (pp. 259-288). New York, USA: CABI publishing.

Speiser, B. \& Rowell-Rahier, M. (1991). Effects of food viability, nutritional value and alkaloids on food choice in the generalist herbivore Arianta arbustorum (Gastropoda: Helicidae). Oikos, 62(3), 306-318. DOI: 10.2307/3545495

Suárez, A., \& Fernández, A. (2012). Subnicho estructural y densidad poblacional de Cerion politum maisianum y Polymita brocheri en Paso de los Azules, Maisí, Cuba. Novitates Caribaea, 5, 66-72. DOI: 10.33800/nc.v0i5.125

Szlávecz, K. (1986). Food selection and nocturnal behaviour of the land snail, Monadenia hillebrandi mariposa A.G. Smith (Pulmonata: Helminthoglyptidae). The Veliger, 29(2),183-190.

Thakur, S. (1998). Studies on food preference and biology of giant African snail, Achatina fulica in Bihar. Journal of Ecobiology, 10(2), 103-109.

Vetter, J. (2018). Secondary metabolites of ferns. In H. Fernández (ed.) Current Advances in Fern Research (pp. 305-327). Cham, Switzerland: Springer.

Wagner, G. J. (1991). Secreting glandular trichomes: more than just hairs. Plant physiology, 96(3), 675-679. DOI: 10.1104/pp.96.3.675

Wäreborn, I. (1970). Environmental factors influencing the distribution of land molluscs of an oligotrophic area in southern Sweden. Oikos, 21(2), 285-291. DOI: 10.2307/3543685

Westerbergh, A., \& Nyberg, A. B. (1995). Selective grazing of hairless Silene dioica plants by land gastropods. Oikos, 73(3), 289-298. DOI: $10.2307 / 3545953$ 
Wiesenborn, W. D. (2003). White desertsnail, Eremarionta immaculata (Gastropoda: Pulmonata), activity during daylight after winter rainfall. The Southwestern Naturalist, 48(2), 202-207. Retrieved from https://www.jstor.org/stable/3672316

Williamson, P., \& Cameron, R. A. D. (1976). Natural diet of the landsnail Cepaea nemoralis. Oikos, 27(3), 493-500. DOI: $10.2307 / 3543468$

Wink, M. (1988). Plant breeding: importance of plant secondary metabolites for protection against pathogens and herbivores. Theoretical and applied genetics, 75(2), 225-233. DOI: 10.1007/BF00303957

Edited by Melissa Garro Garita. 